Copyright $\odot 2004$ SAGE Publications (London, Thousand Oaks, CA and New Delhi) 1468-7968

Vol 4(3): 381-401;045240

DOI:10.1177/1468796804045240

www.sagepublications.com

\title{
Law and politics in post-modern California
}

Coalition or conflict between African Americans, Asian

Americans, and Latina/os?

\section{KEVIN R. JOHNSON ${ }^{1}$}

University of California, Davis, USA

\begin{abstract}
This article considers the future of relations between African Americans, Asian Americans, and Latina/os in the political process in the United States and evaluates the prospects for social change. To do so, this article focuses on Los Angeles, California, which for a number of years has experienced the demographic change that is beginning to be replicated across the nation. Particular attention is paid to interethnic conflict and the need to redefine the conventional 'civil rights' discourse to reflect the changing socio-economic landscape of postmodern California.
\end{abstract}

KEYWORDS civil rights $\bullet$ coalition building $\bullet$ demographic change $\bullet$ Latino politics

\section{INTRODUCTION}

The law, in combination with changing demographics, has deeply affected political relations between various racialized groups in California, the most racially diverse state in the United States. How the Golden State responds to the ferment brought by such change may be the bellwether for the future of the entire nation. History reveals both the possibility of emerging political coalition and increasing social conflict between African Americans, Asian Americans, and Latina/os.

As in the past, political cooperation may focus on seeking changes in the law designed to improve the status of minorities in US society. Conflict obviously would thwart such efforts at positive change. Fragmented minority communities, even if in combination they constitute a majority of 
the population, will be unable to break any political stalemate. To avoid the risk of allowing the maintenance of white hegemony because of fissures between minority communities, activists must figure out how to build coalition and minimize conflict (Guinier and Torres, 2002; Oh, 1993; Yamamoto, 1999).

In January 2003, 'Hispanics' officially became the largest minority in the United States. According to the 2000 US Census, Hispanics constitute over 32 percent of California's population, with African Americans at over 6 percent, Asians at about 11 percent, and whites at 47 percent (California Department of Finance, 2003: 19 (Table B-5)). Minorities as a whole (49\%) thus outnumber whites (47\%) in California. Today, a majority of the babies born in California are Latina/o. In the state's largest urban area, Los Angeles County, Hispanics constitute over 44 percent of the population, by far the largest group, with African Americans at over 9 percent, Asians at nearly 12 percent, and whites at about 31 percent. To add to the demographic (and thus political) complexities, over one-fourth of the Golden State's population is foreign born, with some immigrants having naturalized to become citizens (and thus eligible voters) while others have not (California Department of Finance, 2002: 1, 16 (Tables 1, 25)).

Communities have adapted to the demographic changes. As their numbers grew, Mexican American women in Los Angeles, for example, organized politically to resist changes that threatened their communities. (Pardo, 1998). In the 1990s, Asian Americans and Latina/os worked constructively on a mutually acceptable city council redistricting scheme in Monterey Park, a Los Angeles suburb that had seen a dramatic shift in its population from Latina/o to Asian American (Chang and Aoki, 1997: 1431-46).

The interaction between minority groups in California, however, has not always been constructive but at times has been marred by conflict, with perhaps the most publicized in recent years being Korean American/ African American tensions in south central Los Angeles (Sonenshein, 1993). Although far less dramatic, Latina/os and African Americans have at various times been at odds politically. For example, a prominent African American Los Angeles County supervisor championed a controversial ordinance passed by the Los Angeles County Board of Supervisors regulating solicitation of work by day laborers (many of whom are Latina/o immigrants), which Latina/os (including a Latina Los Angeles County supervisor) characterized as racist (Johnson, 2002a: 934). The polarized vote in the City of Los Angeles 2001 mayoral election, in which Latina/o voters overwhelmingly backed a progressive Latin candidate while African Americans strongly supported the successful white liberal, also shows the potential for political division between Blacks and Browns in greater Los Angeles.

To complicate matters, intragroup conflict may - and has to a certain extent already - emerged in the political process. In 1992, two African 
American women (Yvonne Braithwaite Burke and Diane Watson) fought a no-holds-barred campaign to become the first African American on the Los Angeles County Board of Supervisors (Simon, 1992a; Simon, 1992b). One reason for the ferocity of the campaign was that 'Watson [saw] herself as a genuine part of the South LA community and Burke as a carpetbagger.' (Boyarsky, 1992). In 2002, a Latino Los Angeles city council candidate accused opponent Antonio Villaraigosa of being a 'pocho, a derogatory term for a person of Mexican ancestry deemed to be too assimilated or too 'white' (Daunt, 2002). Along these lines, the Asian American community is so heterogeneous that building pan-Asian coalitions has proven difficult (Hing, 1993b; Võ, 1999).

Intra-Latino tensions erupted in Cano v. Davis ${ }^{2}$ in which the Mexican American Legal Defense and Education Fund accused the California Legislature, with a record number of Latina/os, of diluting Latina/o voting power in violation of the Voting Rights Act in the state's congressional redistricting scheme. This visible conflict within the Mexican American community, which is generally more cohesive than the greater Latina/o community, suggests the possible splintering of Latina/os along political, national origin, and other lines. In the long term, for example, one could envision a voting rights claim brought by Central Americans, who comprise a significant percentage of the Latina/o population in Los Angeles County, contending that they are being locked out of the electoral process by politicians of Mexican ancestry, who comprise the vast majority of Latina/os in local and state elected offices.

This article, through the lens of the law, considers the future of relations between African Americans, Asian Americans, and Latina/os in the political process in the United States and evaluates the prospects for social change. To do so, this article focuses on Los Angeles, California, which for a number of years has experienced the growing pains of the demographic changes that are beginning to ripple across the nation. The south and midwest, for example, have seen explosive growth in the Mexican immigrant population in recent years (Hing, 2002: 864-68; Lazos Vargas, 2002a; Suro and Singer, 2002).

Despite the much-publicized demographic changes, political coalition between minority groups in California - or, for that matter, across the United States - is not inevitable and should not be assumed. The push to promote multiracial cooperation after the 1992 violence in Los Angeles, triggered by the acquittal of Los Angeles Police Department (LAPD) officers shown on videotape beating African American Rodney King, proved short-lived. Conflict between minorities competing for scarce resources in the political process might just as well be the future as cooperation. Activists will need to devote themselves to strategies that promote coalition between groups or risk divisions that allow minority communities to be divided. 
One important barrier to inter-group cooperation has been the traditional view of civil rights matters as almost exclusively black and white in nature and scope. Given the changing demographics, most knowledgeable observers understand that the struggle for civil rights is considerably more complicated than that today. Asian Americans, Latina/os, Native Americans, and other groups press for recognition and redress of their civil rights concerns, some which differ in important respects from those of African Americans. The question then becomes how to approach the complexities so that practical action can be taken (Lazos Vargas, 2002b). At a minimum, a change in the understanding of what constitutes 'civil rights' is essential to any hope for multiracial alliance.

Another rarely-discussed barrier to multiracial coalitions is racism within minority communities. Anti-African American animus exists in the Latina/o community, just as it exists among certain segments of the Asian American community. Some African Americans have embraced xenophobic views toward Latina/os and Asians. Integration and assimilation of certain groups into US society has at times meant adoption of racist attitudes toward other groups (Johnson, 1997b: 1274; Morrison, 1994). Although such racism is decried, its roots and impacts have gone largely ignored. Racism within communities of color causes tension that hinders political cooperation, generates suspicion, and flares up in times of social turmoil. Those communities must squarely address it.

Political coalitions between minority groups will become increasingly important as demographic changes continue in California and across the US. The United States is just beginning to come to grips with its multicultural and multiracial society. More potential fissure points will come with increasing diversity and cultures. In nations around the world, coalition governments, often but not always composed of different racial and ethnic groups, are a necessary fact of political life; governments fall when coalitions crumble. This dynamic in certain respects may represent the future of the United States. With the end of Anglo numerical superiority will come the need for coalitions for progress to be secured. In fact, coalitions in all likelihood will be necessary to simply govern at all. Ultimately, the demographic changes offer both opportunity and danger, for progress and retrenchment, for both equality and oppression.

Political coalitions have been the subject of study in Critical Race Theory (CRT) scholarship, with many critical scholars believing that racial justice requires political as well as legal solutions (Rosenberg, 1991; Spann, 1993). CRT scholars have advocated coalitions between different minority groups (Martínez, 1998; Williams, 1994). Coalition building is also a strategy for social change endorsed by emerging critical Latina/o, or LatCrit, theory (Valdes, 1997: 1094). Of course, coalition building faces formidable barriers (Banks 1998). As influential CRT scholar, Angela Harris, has correctly emphasized, 'solidarity is the product of struggle, not wishful thinking; and 
struggle means not only political struggle, but moral and ethical struggle as well' (Harris, 1994: 784; Lawrence, 1995).

However, some CRT scholars, including Richard Delgado, dismiss efforts to build multiracial coalitions in the quest for racial justice and contend that independent groups should pursue their own self-interest in social justice as opposed to building coalitions (Delgado, 2003: 856, 884; Trask, 1991). In some ways, the debate among Critical Race Theorists over coalition building mirrors that between the nationalist and broad-based political movements of the 1960s (Carmichael and Hamilton, 1968: 58-84). This paper falls into the coalition camp. Racial justice requires political coalitions to bring about social change. The choice is between whether we work together or allow the status quo to remain.

\section{CONFLICT AND CONFLUENCE AMONG MINORITIES ON CIVIL RIGHTS ISSUES}

African Americans, Latina/os, and Asian Americans in California have had ambiguous political relations throughout California's history. They often have treated each other as competitors for scarce resources rather than as potential political allies in the quest for racial justice. This, however, has not always been - and need not necessarily be - the case.

Lasting social change will require political coalitions and cooperation. To build coalitions, we must recognize that African American, Asian American, and Latina/o communities have interests that may diverge on certain issues. It is not the case that the core civil rights issues are the same for African Americans, Latina/os, and Asian Americans. At times, the proposed solutions to community-specific problems may conflict. Differences must be discussed candidly and honestly to discern whether coalitions are possible on some issues. The need will be to focus on the building of coalitions on specific issues when possible.

Coalition opportunities exist between various minority groups on certain issues. However, such possibilities would need sustained commitment if they are to come to fruition. In addition, we must begin to address a fundamental division - racial discrimination - between minority groups.

\section{DISCRIMINATION}

The Golden State has a rich history of discrimination against African Americans, Asian Americans, and Latina/os, and Native Americans (Almaguer, 1994). Although different groups have been attacked with 
ferocity at different historical moments in California's history, they all have been generally subject to segregation and discrimination in housing, employment, and education.

Discrimination against racial minorities has been on the rise since the tragic events of September 11, 2001 (Akram and Johnson 2002; Cole 2002; Volpp 2002). Racial profiling in law enforcement has made a comeback. Federal, state, and local law enforcement efforts officers have targeted Arabs and Muslims in the 'war on terror.' All immigrants, including many from Mexico, the largest immigrant population in the United States, have suffered the consequences of increased border enforcement since September 11. This had lead to nascent political coalitions among Asian American, Latina/o, and other groups protesting the treatment of Arab and Muslim noncitizens subject to special immigration requirements. In January 2003 in Los Angeles, for example, mass protests followed the arrest and detention of Iranian noncitizens, of which a significant population lives in southern California, who went to the Immigration and Naturalization Service to 'register' pursuant to regulations issued by the Attorney General (Buchanan, 2003; McGann, 2003; Watanabe, 2003).

African Americans, Asian Americans, and Latina/os are sensitive to perceived racial discrimination by whites, one common thread to their experiences in the United States (Tamayo, 1995: 23-25). At times, different groups may act in isolation to combat discrimination against their particular community, with less concern for discrimination against other groups. As the times we live in demonstrate, this myopic view has proven to have had limited political effectiveness.

One complication to the formation of coalitions is that African Americans have claimed that whites prefer Latina/os over them in employment because Latina/os are effectively 'white' (Miles, 1992). In this vein, some scholarship contends that immigrants, including many Asians and Latina/os, lower the wage scale and adversely affect poor and working class African Americans (Briggs, 2003). This brings us to a major dividing line between African Americans and other minority groups - immigration.

\section{IMMIGRATION}

Immigration has emerged as a pressing civil rights and racial justice issue in the United States. It is especially important in California, with its large immigrant population as well as significant US-born Mexican American and Asian American populations. African Americans, Asian Americans, and Latina/os have not always been on the same page with respect to immigration law and its enforcement. Indeed, immigration often has been a dividing line, particularly between African Americans, most of whom are 
native born US citizens, and Latina/os and Asian Americans, communities with large immigrant populations (Johnson, 1995a: 57-63). Immigration enforcement adversely impacts large segments of the Latina/o and Asian American communities, with less tangible impacts on African Americans. Latina/o and Asian American citizens are likely to be stopped and questioned about their immigration status because of their physical appearance (Johnson, 2000). Both groups generally are presumed to be foreigners, even if their ancestors have been in this country for generations (Johnson, 1997a: 352-58; Saito, 1997). Immigration and immigration enforcement thus is a civil rights issue of importance for Asian Americans and Latina/os.

Differences of perspective about immigration play out in the political process. African Americans and Asian Americans were more supportive than Latina/os of the anti-immigrant landmark Proposition 187, a California initiative that would have stripped undocumented immigrants of all public benefits, including a public education (Johnson, 1995b: 658-59 and n. 144). As this suggests, Asian Americans in the aggregate may view immigration and immigrants somewhat differently than Latina/os. Divergent views among Mexican Americans about immigration and immigrants also exist (Gutiérrez, 1995).

Immigration may be viewed as contributing to the subordination of African Americans. Poor and working-class African Americans may feel in competition with low-wage immigrant labor. Consequently, they may view immigrants as an economic threat and, as a result, may lean toward restrictionist immigration measures. African Americans generally have been more inclined than Latina/os or Asian Americans to support antiimmigrant measures (Fuchs, 1990).

This perception of immigrants and the civil rights of immigration may be changing. African American leaders have identified racial discrimination as the reason for the disparate treatment of Cuban and Haitian immigrants, most of who are of African ancestry, by the federal US government. In addition, African Americans are profiled as drug dealers (and sometimes as immigration violators) at the border. Nonetheless, rank-and-file African Americans generally do not see curbing overzealous immigration enforcement as a core civil rights concern as Latina/os and Asian Americans do. This may be attributable to the fact that immigration law and its enforcement is central to the history and daily life of Latina/os and Asian Americans but not that of most African Americans.

\section{CRIMINAL JUSTICE}

Racism in law enforcement is an issue of central importance to Latina/os and African Americans. In certain areas of the United States, it is an issue 
of importance to the Asian American community as well. All of these groups have an interest in removing the impermissible consideration of race from law enforcement, in immigration as well as ordinary criminal investigation (Johnson, 2003a; Martínez, 1998; Piatt, 1997; Vaca, 2004). Such fears have grown in significance after the resurgence of racial, ethnic, national origin, and religious profiling in the 'war on terror' after September 11. As the racism that historically has permeated the notorious LAPD illustrates, discrimination against one minority group lives comfortably with discrimination against others. LAPD's Ramparts Division brutally enforced the laws against African Americans and Latina/os, with the immigration laws used as an additional law enforcement tool. Depending on the locale, law enforcement has directed attention at 'gang' activity in Latina/o, African American, and Asian communities.

Although their experiences differ from those of African Americans and Latina/os, Asian Americans to a certain extent are subject to stereotypes that negatively impact on them in the criminal justice system. The Wen Ho Lee case, in which a naturalized US citizen of Chinese ancestry was falsely accused of turning over national secrets to the Chinese government, is a high-profile example of a 'foreigner' presumed to be a threat to national security and subject to the federal government's arsenal of weapons in the criminal justice system (Gotanda, 2000; Joo, 2002). More commonly, in certain locales, police stereotype Asian American youth as presumptive gang members (Kim, 1996; Russell, 1992).

Importantly, socioeconomic class influences views on criminal justice. For that reason, African Americans and Latina/os, more concentrated among poor and working people, may fear police abuses more than Asian Americans, many of whom are not. Asian Americans may seek more police protection from these 'criminal elements.' This was an undercurrent to the Korean American/African American conflict in Los Angeles in the events culminating in the violence in May 1992.

Each minority group could act in its own self interest and seek to remove discriminatory police practices directed at them specifically, without efforts to protect other groups from such abuses. This strategy historically has proven to be self-defeating and has left us where we are today. Unified action and political pressure is necessary to remove race from the law enforcement process in its entirety.

\section{EMPLOYMENT AND CLASS}

Employment discrimination and wage and working condition standards some might label them 'economic justice' concerns - are an issue for all minority groups. African Americans, Asian Americans, and Latina/os 
have long suffered discrimination in California. Today, Latina/o and Asian immigrants are subject to employment discrimination. Class-based movements, along multiracial and across immigration statuses, hold much promise (Cummings, 2001; Montoya, 2001). Efforts to improve the status of undocumented workers might translate into improvements for citizen workers.

For example, the fact that, under federal labor law, employers who engage in unlawful union busting activities cannot be required to pay back-pay to undocumented workers, chills union organizing efforts by undocumented immigrants (and probably all workers). ${ }^{3}$ To the extent that employers are encouraged to employ low-wage, non-union, and undocumented labor, this undercuts the wage scale for other workers. If one accepts the reality that undocumented workers will continue to participate in the labor market (in other words, that border enforcement will not keep them out of the country) (Johnson, 2003b: 245-52), then one should accept that efforts to enforce labor standards can improve the conditions of all workers.

African Americans and immigrants, including Asian and Latina/o immigrants, have a history of class conflict. White workers have also embraced restrictionist measures in times of economic distress (Higham, 1994 70-72). Immigrant workers historically have been blamed for undercutting domestic workers in the labor market. Organized labor, however, has come to see its future in organizing, not demonizing, immigrant labor (Johnson, 2002b). This change of heart increases the likelihood of developing class-based coalitions along multiracial lines.

Class should be a particularly viable strategy for building coalitions among African Americans and Latina/os, who on the average find themselves at the lower end of the socioeconomic spectrum, than Asian Americans, who on the average are not. However, in California, certain large segments of the Asian American community, such as persons of Southeast Asian ancestry, share common class interests with African Americans and Latina/os (Ong and Hee, 1994). Such interests create the potential for multiracial coalitions along class lines (Romero, 2000). Common class interests in the past allowed Mexican and Filipino farm workers, for example, to work together in Cesar Chavez's United Farm Worker union (Acuña, 1988: 325).

Grassroots organizing will be necessary. Successful social justice movements in recent years have begun from the bottom up in Los Angeles. Janitors for Justice, the Drywallers' labor organizing efforts, and other recent successful labor organizing efforts were multiracial and extended to immigrant as well as citizen workers (Cameron, 1999: 1091; Garcia, 2003: 526-30; Milkman, 2000). Labor unions in recent years have embraced organizing immigrant workers, rather than expending political capital in seeking restrictionist legislation designed to bar them from the country (Crain, 2002: 228-29; Garcia, 2002: 100-02). Along these lines, a multiracial 
community-based Bus Riders Union successfully demanded adequate inner-city bus service in Los Angeles (Mann, 1999: 775-87).

Class-based concerns outside the workplace also may hold the potential for multiracial coalition. Consider the issues below.

\section{EDUCATION AND AFFIRMATIVE ACTION}

Moving away from the workplace, education and affirmative action may ensure the possibility of class mobility and access to economic opportunity. Education and affirmative action tend to be important to those groups seeking access to economic opportunity, including African Americans, Latina/os, and certain Asian national origin groups who are particularly interested in educational equity.

African Americans more strongly supported affirmative action, designed generally to ensure access to higher education, and opposed California's Proposition 209, which eliminated such programs in the state, than Latina/os and Asian Americans (Gee, 2001: 41). All minority groups opposed the measure, however. Divides exist and some claim that Asian Americans have benefited from the end of affirmative action in California, Texas, and elsewhere.

The much-publicized dispute about the complex admissions system at Lowell High School, the flagship public high school in San Francisco, is an example of conflict over educational access at the local level. In that case, a court imposed a consent decree in a school desegregation case designed to ensure a diverse student body, including African Americans and Latina/os; the system was later challenged as discriminating against Chinese American students. Conflict between the interests of Chinese Americans and African Americans and Latina/os was evident. Tensions between different groups over the rules of admission at Lowell High School remain to this day (Yamamoto, 1997).

\section{HOUSING AND PUBLIC SCHOOLS}

Closely correlated to socioeconomic class, housing segregation is a general issue for minority communities (Calmore, 1998). 'Hypersegregation' is the term coined to describe the severe residential segregation of African Americans and Latina/os (Massey and Denton, 1989: 373). All minority groups can agree that the anti-discrimination laws should be vigorously enforced in employment and housing.

Given that public schools are organized along local lines and affected by 
residential segregation, public school issues at times generate racial tensions and conflict. Equality in financing of public schools has grown in importance, as the inequalities have become more glaring, with residential segregation persisting. The budget crisis faced by California early in the 21st-century may increase the conflicts over resources between groups.

\section{PUBLIC BENEFITS}

The debate over welfare historically has been racialized in the United States, with African Americans and Latina/os long identified as welfare abusers. In recent years, elderly Asian immigrants have been stereotyped in the same way (Hing, 1998: 167-70). Such stereotypes resulted in the elimination of most federal benefits to lawful immigrants in the 'welfare reform' in 1996, which was combined with amendments to the immigration laws, making it more difficult for immigrants of modest means to bring relatives into the country (Hernandez-Truyol and Johns, 1998).

Multiracial coalitions may challenge the racial stereotypes that dominate the public discussion of welfare in the United States.

\section{VOTING RIGHTS AND POLITICAL PARTICIPATION}

Voting rights litigation may create fissures between minority communities. African Americans, Asian Americans, and Latina/os may see themselves at odds in future voting rights litigation on issues such as redistricting and representation. The result of these differences could well be political gridlock, as has occurred in the past.

It undisputedly is the case that, as Latina/os have sought to claim political power, tensions have resulted between Blacks and Latina/os on voting rights matters. In the absence of careful planning, Latina/os could be fighting Latina/os, as was the 2003 California redistricting case of Cano $v$. Davis. For example, immigrants and citizens, even if of the same ancestry, may have different political issues and class positions.

Voting rights litigation has increased in complexity because of the need to consider the needs of a multiracial America. Courts have recognized that Asian Americans, African Americans, and Latina/os have divergent voting patterns and interests. For example, in the case of Johnson v. DeGrandy, ${ }^{4}$ Latina/os and African Americans in Florida challenged a redistricting plan as diluting the voting strength of African Americans and Latina/os; the district court found a remedy for both groups of plaintiffs to be mutually exclusive (Ramirez, 1995). Demographic differences among Latina/os and 
African Americans in terms of citizenship and age, which affect electoral participation, complicate matters.

Efforts to increase voter turnout among eligible voters will likely help all minority communities because minority turnout often has been relatively low. Other strategies stand to benefit different communities differently in the political process. Naturalization campaigns that transform disenfranchised immigrants into citizens eligible to vote are most likely to benefit Latina/os and Asian Americans with significant noncitizen populations. As this suggests, efforts at political mobilization, which to be successful must address different histories and needs, may vary by community. Ultimately, one could envision both group-specific and general strategies to promote electoral participation by African Americans, Asian Americans, and Latina/os.

Efforts at political mobilization are likely to face resistance. In the 1990s, for example, the Clinton administration launched Citizenship USA, which was designed to facilitate naturalization by immigrants, but was later attacked as a partisan political tool to increase Democratic votes (Kelly, 1998: 204-08).5 Similarly, mass mobilization by protesters waving Mexican flags at demonstrations in Los Angeles was used by supporters of Proposition 187 to claim that the opposition was un-American (Bosniak, 1996: 567 n. 29).

Individual political races have seen African Americans, Asian Americans, and Latina/os at odds. More generally, African Americans have made in-roads into political representation in recent years, after formally and informally being locked out of the political process for generations. African Americans may view redistricting as benefiting Asian Americans and Latina/os at the expense of African Americans. In some cities, such as the working-class Los Angeles suburb of Compton, Latina/os seek to ensure electoral representation and claim that African Americans are overrepresented in city government (Hing, 1993a). Conflicts over redistricting already have arisen, including conflicts between Latina/os and African Americans.

The 2002 call for secession in Los Angeles, which effectively was a movement for massive redistricting and boundary redrawing issue, had racial overtones as well (Bourdreau and Keil, 2001). The San Fernando Valley, with its large Latina/o population and healthy tax base, sought to secede from Los Angeles, which would have left many African Americans in the inner city, with fewer governmental resources at their disposal due to the loss of tax revenues. On the defensive, secessionists denied that the move to leave Los Angeles was a form of 'white flight' from the inner city. Although some observers believed that Latina/os would gain from secession, Latina/os ultimately did not support the measure. Asian Americans also opposed secession. Thus, a multiracial coalition helped to defeat a measure that would have redefined the political boundaries of Los Angeles. 


\section{COALITION OR CONFLICT?}

Despite differences, political coalitions between and among minority groups remain necessary and possible. Although the demographics of California are rapidly changing, that does not necessarily translate into changing electoral outcomes. Limits on voter eligibility and low voter turnout remain significant issues for African Americans, Latina/os, and Asian Americans.

Importantly, a significant number of Latina/os and Asian Americans in the state are legal or undocumented immigrants who as noncitizens are not eligible to vote. The disenfranchisement of convicted felons has significant impacts on Latino and African American male voter eligibility, given the disparate impact of the criminal justice system on those communities. (Calmore, 2001: 1277-80). For a variety of reasons, voter turnout traditionally has been lower among minority communities than white communities. Consequently, Victor Valle and Rodolfo Torres have analyzed the impediments to the exercise of political power by Latina/os in Los Angeles dubbed the 'Latino Metropolis' - despite their growing numbers (Valle and Torres, 2000: 167-94).

A recent study demonstrates the need for coalition between racial minorities in California, a state where the numbers seem to favor minority interests more than other states:

By 2040, whites are projected to be little more than one-third of the adult population of California. However, if the citizenship and [voter] turnout rates of Asians and Latinos remain at their 2000 levels, whites will still make up a majority (53 percent) of the population. (Citrin and Highton, 2002: $\mathrm{x}$ )

In light of the limits on electoral power even with changing demographics, coalitions among minority communities will be necessary if they want to destabilize white privilege. African Americans, however, have felt threatened by Latina/o and Asian American electoral gains. In California, infighting and fragmenting of minority communities could result in racial minorities losing out.

Los Angeles has been said to be the place for development of the progressive politics of the future, in part because the 2001 mayoral election saw a runoff between a white liberal and progressive Latino (Keil, 2002). However, the mayoral race also reveals the simmering tensions between African Americans and Latina/os. Rather than noting a progressive shift, it might suggest increasing inter-ethnic tension. Only time will tell. Election advertisements of the white candidate played on racially charged themes, with bad blood remaining after the election. It remains to be seen whether minorities will side with whites in future elections. If Los Angeles is to become the new progressive model, coalitions will need to be formed. 


\section{INTER-ETHNIC CONFLICT}

There has been much publicized inter-ethnic conflict between minority groups, as well as with the Anglo population (Hing, 1993a). In the wake of the Rodney King violence of May 1992, African American and Korean American conflict grabbed the headlines (Ikemoto, 1993; Robinson, 1993), even though many of the people involved in the violence were Latina/o.

Conflict between minority groups has been sensationalized and arguably has been over-emphasized (Johnson, 1999: 226-7). At least in major civil rights litigation, minority activist organizations historically have cooperated. For successful cooperation in the future, community work will be necessary to identify and build common ground on some major issues, such as discrimination, immigration, employment, criminal justice, and voting rights.

Minority groups will need to address racism within their communities toward other minority communities. To this point, little has been done to address the racism within minority communities, although few would deny that it exists. Latina/o, Black, and Asian American relations are marred by discrimination toward each other as well as interactions with whites.

Racism against minorities among minorities may result in coalitions between Latina/os and other groups, including whites. Richard Delgado has suggested that minority groups bargain with each other rather than try to cut the best deal with whites (2000: 288-306). At various times in the past, Latina/os and Asian Americans have identified as 'white' (Martínez, 1997; $\mathrm{Wu}, 1996)$. In light of history and physical difference, coalitions with whites appear more likely for Latina/os than for Asian Americans and African Americans. However, Latina/os have historically been racialized in the United States and segments of the community have a well-developed racial consciousness (Haney, 2003). At times, blacks and whites have joined forces to support restrictionist immigration measures that have damaged Latina/os and Asian Americans.

The future of coalitions is far from certain. Whites, reminiscent of the Republican Party's current efforts to court Latina/o voters, will look to build alliances with minority groups. Whether that strategy will work remains to be seen.

\section{INTRA-ETHNIC CONFLICT}

Intra-ethnic conflict is an issue as well. Asian Americans and Latina/os are heterogeneous communities. Consequently, efforts must be made to build coalitions within as well as among minority communities. Similar, class and 
other cleavages may divide the African American community. Specifically, a burgeoning Black middle class may not share the class-based concerns of poor and working class African Americans (Hochschild, 1993).

To this point, intra-community schisms have been under-analyzed. Fissures within the Asian American, African American, and Latina/o communities are visible yet ignored. This is evident among Latina/os, who differ socioeconomically and politically along national origin lines. Similarly, Asian Americans are far from a monolithic community with national origin, political, and class differences. Few American-born Filipinos, for example, attend college or graduate school, despite being one of the largest Asian groups in the United States. Asian American diversity is a formidable hurdle to a pan-Asian identity (Chew, 1995). This is true even though all Asian Americans often are discriminated against as 'foreign' (Saito, 1997).

In sum, intra-group cooperation cannot be assumed. Rather, coalition between minorities must be built carefully and with sensitivity.

\section{CONCLUSION}

It is obviously difficult to speculate about future events. In terms of coalition and conflict between minority groups in the political process in California, the past suggests that the future holds the potential for both. Whatever the demographic changes, it will be necessary for coalitions to be built among minority groups to ensure that their civil rights agenda is respected. No one group is likely to command the demographic margin necessary to ignore the need for cooperation. Time will tell whether African Americans, Latina/os, and Asian Americans will be able to work together in the political process or whether conflict and confusion will reign, with some groups siding with whites in pursuit of apparent self-interest.

California currently is seeing more demographic change than the rest of the nation. If the past is a prelude, however, we may well see similar demographic changes occur throughout the United States. In that event, the political changes in the Golden State may well replicate themselves in other states. Cooperation in California will set the stage for later coalition in other states. Conflict, however, could commence a negative pattern that could be replicated across the United States. Racism is a major impediment to the trust necessary for coalition-building.

Consequently, inter-ethnic conflict must be addressed. One modest step is to expand the notion of 'civil rights' to include grievances of all minority groups. Importantly, racism with communities of color against other people of color, as well as conflict within communities of color, must be acknowledged and addressed. 


\section{Notes}

1 A few of the arguments in this article are elaborated in greater detail in Johnson, 2003c: 759.

2. 211 F. Supp. 2d 1208 (C.D. Cal. 2002), affirmed, 537 U.S. 1100 (2003).

3 Hoffman Plastic Compounds, Inc. v. NLRB, 535 U.S. 137, 144 (2002).

4 See DeGrandy v. Wetherell, 815 F. Supp. 1550, 1569 (N.D. Fla. 1992), affirmed in part, reversed in part sub nom., Johnson v. DeGrandy, 512 U.S. 997 (1993).

5 Later investigations failed to uncover evidence of the charge that naturalization was used for partisan purposes (Interpreter Releases, 2000).

\section{References}

Acuña, Rodolfo F. (1988) Occupied America: A History of Chicanos (3rd edition). New York: Harper \& Row.

Akram, Susan M. and Kevin R. Johnson (2002) 'Race, Civil Rights, and Immigration Law After September 11, 2001: The Targeting of Arabs and Muslims', N.Y.U. Annual Survey of American Law 58(3): 295-355.

Almaguer, Tomás (1994) Racial Fault Lines: The Historical Origins of White Supremacy in California. Berkeley, CA: University of California Press.

Banks, Tauyna Lovell (1998) 'Both Edges of the Margin: Blacks and Asians in Mississippi Masala, Barriers to Coalition Building', Asian Law Journal 5(1): 7-40.

Bosniak, Linda S. (1996) 'Opposing Prop. 187: Undocumented Immigrants and the National Imagination', Connecticut Law Review 28: 555-620.

Boudreau, Julie-Anne and Roger Keil (2001) 'Seceding from Responsibility? Secession Movements in Los Angeles', Urban Studies 38(10): 1701-731.

Boyarsky, Bill (1992) 'A County Revolution in the Making', Los Angeles Times 26 August: B2.

Briggs, Vernon M., Jr (2003), Mass Immigration and the National Interest: Policy Directions for the New Century (3rd edition). Armonk, NY: ME Sharpe.

Buchanan, Wyatt (2003) 'Hundreds Protest INS Registration', San Francisco Chronicle 11 January: A13.

California Department of Finance (2002) California Current Population Survey Report: March 2001 Data. Sacramento, CA: California Department of Finance.

California Department of Finance (2003) California Statistical Abstract: 2003. Sacramento, CA: California Department of Finance.

Calmore, John O. (1998) 'Race/ism Lost and Found: The Fair Housing Act at Thirty', University of Miami Law Review 52(4): 1067-130.

Calmore, John O. (2001) 'Race-Conscious Voting Rights and the New Demography in a Multiracing America,' North Carolina Law Review 79(5): 1253-281.

Cameron, Christopher David Ruiz (1999) 'The Labyrinth of Solidarity: Why the Future of the American Labor Movement Depends on Latino Workers', University of Miami Law Review 53(4): 1089-117.

Carmichael, Stokely and Charles V. Hamilton (1968) Black Power: The Politics of Liberation in America. London: Cape.

Chang, Robert S. and Keith Aoki (1997) 'Centering the Immigrant in the Inter/National Imagination', California Law Review 85(5): 1395-447. 
Chew, Pat K. (1995) 'Asian Americans: The "Reticent" Minority and Their Paradoxes', William and Mary Law Review 36(1): 1-94.

Citrin, Jack and Benjamin Highton (2002) How Race, Ethnicity, and Immigration Shape the California Electorate. San Francisco, CA: Public Policy Institute of California.

Cole, David (2002) 'Enemy Aliens', Stanford Law Review 54(5): 953-1004.

Crain, Marion (2002) 'Whitewashed Labor Law, Skinwalking Unions', Berkeley Journal of Employment and Labor Law 23(2): 211-58.

Cummings, Scott L. (2001) 'Community Economic Development as a Progressive Politics Toward a Grassroots Movement for Economic Justice,' Stanford Law Review 54(3): 399-494.

Daunt, Tina (2002) 'Flier Attacking Villaraigosa Called "Racist"', Los Angeles Times, 9 November, part 2: 1.

de la Garza, Rodolfo O. and Louis deSipio (1993) 'Save the Baby, Change the Bathwater, and Scrub the Tub: Latino Electoral Participation After Seventeen Years of Voting Rights Act Coverage', Texas Law Review 71(7): 1479-539.

Delgado, Richard (2000) 'Derrick Bell's Toolkit: Fit to Dismantle That Famous House?' New York University Law Review 75(2): 283-307.

Delgado, Richard (2003) 'Linking Arms: Recent Books on Interracial Coalition as an Avenue of Social Reform', Cornell Law Review 88(3): 855-84.

Fuchs, Lawrence (1990) 'The Reactions of Black Americans to Immigration', in Virginia Yans-McLaughlin (ed.) Immigration Reconsidered: History, Sociology, and Politics, pp. 293-314. New York: Oxford University Press.

Garcia, Ruben J. (2002) 'New Voices at Work: Race and Gender Identity Caucuses in the US Labor Movement', Hastings Law Journal 54(1): 79-165.

Garcia, Ruben J. (2003) 'Across the Borders: Immigrant Status and Identity in Law and LatCrit Theory', Florida Law Review 55(1): 511-37.

Gee, Harvey (2001) 'Why Did Asian Americans Vote Against the 1996 California Civil Rights Initiative?' Loyola Journal of Public Interest Law 2: 1-52.

Gotanda, Neil (2000) 'Comparative Racialization: Racial Profiling and the Case of Wen Ho Lee', UCLA Law Review 47(6): 1689-703.

Guinier, Lani and Gerald Torres (2002) The Miner's Canary: Enlisting Race, Resisting Power, Transforming Democracy. Cambridge, MA: Harvard University Press.

Gutiérrez, David G. (1995) Walls and Mirrors: Mexican Americans, Mexican Immigrants, and the Politics of Ethnicity. Berkeley, CA: University of California Press.

Harris, Angela P. (1994) 'The Jurisprudence of Reconstruction,' California Law Review 82: 741-85.

Hernandez, Michael V. (1999-2000) 'Bridging Gibraltar: Latinos as Agents of Reconciliation in Relations Between Black and White America', La Raza Law Journal 11(2): 99-111.

Hernandez-Truyol, Berta Esperanza and Kimberly A. Johns (1998) 'Global Rights, Local Wrongs, and Legal Fixes: An International Human Rights Critique of Immigration and Welfare "Reform"', Southern California Law Review 71(3): 547-615.

Higham, John (1994) Strangers in the Land: Patterns of American Nativism (3rd edition). New Brunswick, NJ: Rutgers University Press. 
Hing, Bill Ong (1993a) 'Beyond the Rhetoric of Assimilation and Cultural Pluralism: Addressing the Tension of Separatism and Conflict in an Immigration Driven Multiracial Society,' California Law Review 81(4): 863-925.

Hing, Bill Ong (1993b) Making and Remaking Asian American through Immigration Policy 1850-1990. Stanford, CA: Stanford University Press.

Hing, Bill Ong (2002) 'Answering Challenges of the New Immigrant-Driven Diversity: Considering Integration Strategies', Brandeis Law Journal 40(4): 861-907.

Hing, Bill Ong (1998) 'Don’t Give Me Your Tired, Your Poor: Conflicted Immigrant Stories and Welfare Reform,' Harvard Civil Rights-Civil Liberties Law Review 33(1): 159-82.

Hochschild, Jennifer L. (1993) 'Middle-Class Blacks and the Ambiguities of Success', in Paul M. Sniderman, Philip E. Tetlock and Edward G. Carmines (eds) Prejudice, Politics, and the American Dilemma. Stanford, CA: Stanford University Press, 148-72.

Ikemoto, Lisa C. (1993) 'Traces of the Master Narrative in the Story of African American/Korean American Conflict: How We Constructed "Los Angeles", Southern California Law Review 66(4): 1581-598.

Interpreter Releases (2000) 'IG Report Finds INS's “Citizenship USA” Program Was Flawed, But Not for Political Reasons', Interpreter Releases 77: 1198.

Johnson, Kevin R. (1995a) 'Civil Rights and Immigration: Challenges for the Latino Community in the Twenty-First Century,' La Raza Law Journal 8(1): 42-89.

Johnson, Kevin R. (1995b) 'An Essay on Immigration Politics, Popular Democracy, and California's Proposition 187: The Political Relevance and Legal Irrelevance of Race', Washington Law Review 70(3): 629-73.

Johnson, Kevin R. (1997a) 'Racial Hierarchy, Asian Americans and Latinos as "Foreigners", and Social Change: Is Law the Way to Go?' Oregon Law Review 76(3): 348-68.

Johnson, Kevin R. (1997b) " "Melting Pot" or "Ring of Fire"? Assimilation and the Mexican-American Experience', California Law Review 85(5): 1259-313.

Johnson, Kevin R. (1999) 'Lawyering for Social Change: What's a Lawyer to Do?' Michigan Journal of Race and Law 5: 201-28.

Johnson, Kevin R. (2000) 'The Case Against Race Profiling in Immigration Enforcement,' Washington University Law Quarterly 78(3): 675-736.

Johnson, Kevin R. (2002a) 'Latina/os and the Political Process: The Need for Critical Inquiry', Oregon Law Review 81(4): 917-39.

Johnson, Kevin R. (2002b) 'The End of "Civil Rights" as We Know It?: Immigration and the New Civil Rights Law,' UCLA Law Review 49(5): 1481-511.

Johnson, Kevin R. (2003a) 'The Case for African American and Latina/o Cooperation in Challenging Race Profiling in Law Enforcement,' Florida Law Review 55(1): 341-63.

Johnson, Kevin R. (2003b) 'Open Borders?', UCLA Law Review 51: 193-265.

Johnson, Kevin R. (2003c) 'The Struggle for Civil Rights: The Need for, and Impediments to, Political Coalitions Among and Within Minority Groups', Louisiana Law Review 63: 759-83.

Joo, Thomas W. (2002) 'Presumed Disloyal: Executive Power, Judicial Deference, and the Construction of Race Before and After September 11', Columbia Human Rights Law Review 34(1): 1-47. 
Keil, Roger (2002) 'Los Angeles as Metaphor: Boiling Frogs, Killer Bees, and Subversive Politics', in Deepak Narang Sawhney (ed.) Unmasking L.A: Third Worlds and the City, p. 199. New York: Palgrave.

Kelly, Linda (1998) 'Defying Membership: The Evolving Role of Immigration Jurisprudence', University of Cincinnati Law Review 67(1): 185-236.

Kim, Claire Jean (2000) Bitter Fruit: The Politics of Black-Korean Conflict in New York City. New Haven, CT: Yale University Press.

Kim, Suzin (1996) 'Gangs and Law Enforcement: The Necessity of Limiting the Use of Gang Profiles,' Boston University Public Interest Law Journal 5(2): 265-85.

Lawrence, Charles R., III (1995) 'Race, Multiculturalism, and the Jurisprudence of Transformation', Stanford Law Review 47(5): 819-47.

Lazos Vargas, Sylvia R. (2002a) " "Latina/o-ization" of the Midwest: Cambio de Colores (Change of Colors) as Agromaquilas Expand into the Heartland' Berkeley La Raza Law Journal 13(2): 343-68.

Lazos Vargas, Sylvia R. (2002b) 'The Latina/o and APIA Vote Post-2000: What Does it Mean to Move Beyond "Black and White" Politics?' Oregon Law Review 783 81(4): 783-848.

Mann, Eric (1999) 'Radical Social Movements and the Responsibility of Progressive Intellectuals,' Loyola Los Angeles Law Review 12(3): 761-90.

Martínez, George A. (1997) 'The Legal Construction of Race: Mexican-Americans and Whiteness,' Harvard Latino Law Review 2: 321-47.

Martínez, George A. (1998) 'African-Americans, Latinos, and the Construction of Race: Toward an Epistemic Coalition', UCLA Chicano-Latino Law Review 19: 213-22.

Massey, Douglas S. and Nancy A. Denton (1989) 'Hypersegregation in US Metropolitan Areas: Black and Hispanic Segregation Along Five Dimensions,' Demography 26(3): 373-91.

McGann, Chris (2003) 'Protesters Accuse INS of "Very Un-American” Registration', Seattle Post-Intelligencer 14 January: B1.

Miles, Jack (1992) 'Blacks vs. Browns,' Atlantic Monthly October: 67.

Milkman, Ruth, ed. (2000) Organizing Immigrants: The Challenge for Unions in Contemporary California. Ithaca, NY: ILR Press.

Montoya, Margaret E. (2001) 'Class in LatCrit: Theory and Praxis in a World of Economic Inequality', Denver University Law Review 78: 467-505.

Morrison, Toni (1994) 'On the Backs of Blacks,' in Nicolaus Mills (ed.) Arguing Immigration: The Debate over the Changing Face of America, pp. 97-100. New York: Simon \& Schuster.

Oh, Angela E. (1993) 'Race Relations in Los Angeles: "Divide and Conquer" is Alive and Flourishing,' Southern California Law Review 66(4): 1647-51.

Ong, Paul and Suzanne J. Hee (1994) 'Economic Diversity,' in Paul Ong (ed.) The State of Asian Pacific America: Diversity, Issues and Policies: A Public Policy Report. Los Angeles, CA: LEAP Asian Pacific American Public Policy Institute and UCLA Asian American Studies Center: 31-56.

Pardo, Mary (1998) Mexican American Women Activists: Identity and Resistance in Two Los Angeles Communities. Philadelphia, PA: Temple University Press.

Piatt, Bill (1997) Black and Brown in America: The Case for Cooperation. New York: New York University Press. 
Ramirez, Deborah A. (1995) 'Multicultural Empowerment: It's Not Just Black and White Anymore', Stanford Law Review 47(5): 957-92.

Robinson, Reginald Leamon (1993) 'The Other Against Itself': Deconstructing the Violent Discourse Between Korean and African Americans', Southern California Law Review 67(1): 15-115.

Romero, Mary (2000) 'Historicizing and Symbolizing a Racial Ethnic Identity: Lessons for Coalition Building with a Social Justice Agenda', UC Davis Law Review 33(4): 1599-625.

Rosenberg, Gerald N. (1991) The Hollow Hope: Can Courts Bring About Social Change? Chicago: University of Chicago Press.

Russell, Margaret M. (1992) 'Entering Great America: Reflections on Race and the Convergence of Progressive Legal Theory and Practice', Hastings Law Journal 43: 749-67.

Saito, Natsu Taylor (1997) 'Alien and Non-Alien Alike: Citizenship, "Foreignness", and Racial Hierarchy in American Law', Oregon Law Review 76(3): 261-345.

Simon, Richard (1992a) 'Burke, Watson Step Up Attacks', Los Angeles Times 31 October: B1.

Simon, Richard (1992b) 'Burke's Ad Attacks Watson's Campaign on Tie-In to Karlin', Los Angeles Times 25 April: B3.

Sonenshein, Raphael J. (1993) Politics in Black and White: Race and Power in Los Angeles. Princeton, NJ: Princeton University Press.

Spann, Girardeau A. (1993) Race Against the Court: The Supreme Court and Minorities in Contemporary America. New York: New York University Press.

Suro, Roberto and Audrey Singer (2002) Latino Growth in Metropolitan America: Changing Patterns, New Locations. Washington, DC: Brookings Institution.

Tamayo, William R. (1995) 'When the "Coloreds" Are Neither Black Nor Citizens: The United States Civil Rights Movement and Global Migration', Asian Law Journal 2(1): 1-32.

Trask, Haunani-Kay (1991) 'Coalition-Building Between Natives and Non-Natives', Stanford Law Review 43(6): 1197-213.

Vaca, Nicolás C. (2004) The Presumed Alliance: The Unspoken Conflict Between Latinos and Blacks and What It Means for America. New York: Rayo.

Valdes, Francisco (1997) 'Under Construction - LatCrit Consciousness, Community, and Theory', California Law Review 85(5): 1087-142.

Valle, Victor M. and Rodolfo D. Torres (2000) Latino Metropolis. Minneapolis, MN: University of Minnesota Press.

Võ, Linda Trinh (1996) 'Asian Immigrants, Asian Americans, and the Politics of Economic Mobilization in San Diego', Amerasia Journal 22(2): 89-108.

Volpp, Leti (2002) 'The Citizen and the Terrorist', UCLA Law Review 49(5): 1575-600.

Watanabe, Teresa (2003) 'Muslim Panel Riding Wave of Success,' Los Angeles Times 18 January, part 2: 22.

Williams, Robert A., Jr (1994) 'Linking Arms Together: Multicultural Constitutionalism in a North American Indigenous Vision of Law and Peace', California Law Review 82(4): 981-1049.

Wu, Frank H. (1996) 'From Black to White and Back Again,' Asian Law Journal 3(1): 185-215.

Yamamoto, Eric K. (1997) 'Critical Race Praxis: Race Theory and Political 
Lawyering Practice in Post-Civil Rights America', Michigan Law Review 95(4): 821-98.

Yamamoto, Eric K. (1999) Interracial Justice: Conflict and Reconciliation in Post Civil Rights America. New York: New York University Press.

KEVIN R. JOHNSON is Associate Dean for Academic Affairs and Mabie/Apallas Public Interest Professor of Law and Chicana/o Studies at the University of California, Davis. His book How Did You Get to Be Mexican? A White/Brown Man's Search for Identity (Temple University Press, 1999) was nominated for the 2000 Robert F. Kennedy Book Award. He has has also published Race, Civil Rights, and American Law: A Multiracial Approach (Carolina Academic Press, 2001) and Mixed Race America and the Law: A Reader (New York University Press, 2002). In January 2004, Johnson published his latest book The 'Huddled Masses' Myth: Immigration and Civil Rights (Temple University Press). A graduate of Harvard Law School, he served as an editor of the Harvard Law Review. Address: UC Davis School of Law, 400 Mrak Hall Drive, Davis, CA 95616-5201, USA. [email: krjohnson@ucdavis.edu] 